\title{
THE CHALLENGES OF ENGLISH TEACHERS IN REMOTE AREAS TOWARD ONLINE TEACHING DURING COVID-19 PANDEMIC
}

\author{
Niely Fawaidah Virgin ${ }^{1}$, Imam Qalyubi², Zaitun Qamariah $^{3}$ \\ 1,2,3 State Islamic Institute of Palangka Raya \\ ${ }^{1}$ nielyfawaidahvirgin@gmail.com, ${ }^{2}$ imamqalyubi@yahoo.com, ${ }^{3}$ zaitun.qamariah@iain- \\ palangkaraya.ac.id
}

\begin{abstract}
This study aimed at investigating the challenges and identifying the way the English teachers solve the challenges toward online teaching during Covid-19 pandemic. This study was qualitative research. Three instruments were used to collect the data, those are: open-ended questionnaire, interview and documentation. As a result, this study showed that there were eight challenges experienced by the English teachers in remote areas toward online teaching during Covid-19 pandemic, those are: (1) inadequate infrastructure; (2) student's learning attention; (3) financial condition; (4) students readiness; (5) parent's concern; (6) designing materials; (7) measuring student's understanding, and (8) the instability of student's motivation. During teaching-learning process, there were various ways in overcoming the challenges done by the English teachers, those are: (1) create an interactive media; (2) decide the most suitable online learning tool; (3) give additional time for the students; (4) provide adequate facilities for both teacher and student in remote areas.
\end{abstract}

Keywords: Challenge, Covid-19 Pandemic, English Teaching, Online Learning

\section{INTRODUCTION}

Covid-19, which was firstly reported in Hubei. This has become a very vicious virus. This virus has spreaded not only in China but also around the world. According to World Health Organization (2020), this virus had infected more than 38.2 million people around the world, and more than 1.09 million people passed away per October 2020 since this virus appeared in December 2019. This virus causes not only health world crisis but also other sectors in a country such as education. After the Covid-19 has been confirmed as a national disaster. The academic units are stopped, such as course, school and university.

In Indonesia, the government instructs the English language to be learned in every school as a foreign language because English is not used for both first language or second language. English is used just in some condition or sectors such as in a great company, business and tourism because English has a special status among other foreign languages in Indonesia (Lauder, 2008). Even, the government put the English subject as one of the essential subjects which is always examined to the students in the national examination. It is as a sign of how important mastering English is. However, because of the Covid-19 hit, the English teachers really struggle in managing the English class so that the students can master and learn the 4 skills of English itself towards online learning. According to some English lectures who conduct online learning during Covid-19 pandemic, there are several challenges which they have to face, such as, the students who leave in remote areas in Palangka Raya can not connect or follow the online class well because of the bad network in their place of living, the lecturers also 
experience difficulty to use the application to make all the students able to attend and follow the online class well.

To deal with this condition, the English teachers have to give more attention in using the media, such as learning application to guide the students toward online learning and apply it creatively, so the students will not get bored of learning at home. However, the additional needs of the teacher, such as the use of internet and application to support the English teaching is unvoidable. Besides, the continuity of English teaching and learning in some areas also affects the process of teaching and learning. Especially in remote areas, there must be some challenges faced by the English teacher more than the English teacher who teaches in another area. The fact that remote area is an area which has difficult access in internet to conduct online language teaching. The teacher who teaches in remote areas where the students do not have enough needs to held online learning because of the access to the internet and other problems which obstruct the teacher to carry out an online class. Unfortunately, many challenges faced by the English teacher to conduct online language teaching in remote areas during the Covid-19 Pandemic.

In view of the COVID-19 pandemic and the government policy to conduct online learning which both the English teachers and the students have to do learning and teaching activities at home (Kementerian Pendidikan dan Kebudayaan Indonesia, 2020). This research investigates the English teacher challenges in conducting the online teaching in remote areas during COVID-19 Pandemic and identifies the solution to overcome the English teachers' challenges toward online teaching during COVID-19 Pandemic. The subject of this research will be the English teacher in remote areas in Palangka Raya. The researcher also chooses the secondary school English teachers who have at least a year teaching experience because they have higher efficacy to motivate the students in learning and they know various strategy to make the teaching-learning process more interesting for the students.

The reason of why the researcher interested in holding a study entitled "The Challenges Of English Teachers In Remote Areas Toward Online Teaching During Covid-19 Pandemic" is (1) Online learning is widely used in this pandemic to succeed the teaching-learning process. The EFL teachers nowadays utilize the rapid development of technology to help the learning process, such as learning applications, platforms, website, etc. (2) the researcher found several problems faced by the lecturer in conducting online teaching in which the students can not attend and follow the online learning well, (3) the school in remote area applies online learning system during the Covid-19 Pandemic to avoid spreading the virus at school. However, English teachers in remote areas need more preparation in conducting online teaching. They have to think about their teaching equipment and the students' condition in a remote area because sometimes the students can not fill up their necessary to go on online learning because of some reasons. So, it makes the English teachers have to think harder to solve this problem. So that, According to those reasons, the researcher wants to investigate about the English teacher challenges toward the online teaching and the solution of the English teachers overcome their challenges toward online teaching in remote areas in Palangka Raya during the Covid-19 Pandemic. The research questions of this study are:

1. What challenges do the English teachers deal with in carrying out online teaching during COVID-19 pandemic in remote areas?

2. What solution do the English teachers do to overcome the challenges toward online teaching during the COVID-19 pandemic?

The answers of these questions are expected to give the teacher information about the challenges of the English teachers toward online teaching in remote areas. They can also get 
some solutions to overcome the challenges they face during the online teaching during Covid19 Pandemic and be able to be utilized as a reference and information for the school to make the teacher have more creative and innovative English teaching-learning activities

\section{METHOD}

This study was a case study with qualitative approach. As the name implies, a case study is a detailed description of a particular unit. It is in line with Ary, Jacobs, \& Sorensen (2010) said that A case study focuses on a single unit to produce an in-depth, rich, and detailed overview. The participants were five secondary school English teachers who conducted online teaching and had good understanding in digital literacy in remote areas in Palangka Raya. Two instruments were used to collect the data, those are: open-ended questionnaire and interview. Questionare, as described by Babbie in Archaya (2010), is a text containing questions and other types of things intended to solicit information relevant to research. The questions used to collect data were unstructured questions in order to investigate the challenges and the solution of the English teachers toward online teaching. Archaya (2010) An unstructured questionnaire contains open-ended and subjective opinion-type questions. The researcher also used semistructured interview. It is a form of interview that comes under the heading of a deep interview (Sugiyono, 2015, p. 233). Interview was conducted to obtain the teacher's brief explanation about their challenges and they way they overcame the challenges they faced.

\section{RESULTS AND DISCUSSION}

\section{Results}

\section{Challenges of English Teachers}

During educational process carried on online by online learning application or platform, there were several challenges appeared which can be found by distributing the questionnaire and interviewing the English teachers. According to the questionnaire data some teachers stated the challenges they faced, as follows:

Table 1. Questionnaire Data The Challenges of English Teachers in Remote Areas toward Online Teaching during Covid-19 Pandemic

\begin{tabular}{cl}
\hline Participants & \multicolumn{1}{c}{ Answer } \\
\hline Teacher A & Bad signal and mobile data \\
\hline Teacher B & $\begin{array}{l}\text { The instability of student's motivation to join online } \\
\text { learning }\end{array}$ \\
\hline Teacher C & $\begin{array}{l}\text { Mobile data, signal, time and student's ability in using } \\
\text { learning platform }\end{array}$ \\
\hline Teacher D & $\begin{array}{l}\text { The teacher challenge is in explaining the materials } \\
\text { because half of the students have not really understood } \\
\text { the materials }\end{array}$ \\
\hline Teacher E & The students are not always ready when the class begins \\
\hline
\end{tabular}

While the researcher found eight challenges of the English teachers in remote areas toward online teaching during Covid-19 pandemic, those are:

1. Lack of Infrastructure 
Teacher A said, "Considering our students at MTS Al Amin mostly from areas which are far away, such as Habaring Hurung, it is really at the edge and there are no signals. When I use Telkomsel, there are no signals there, except using IM3 or XL. Even, it is low signal. So, the submission time is maximum at 1 p.m because we take the online class till at 10 a.m. the deadline of submission the tas is at 1 p.m. However, the signal is usually bad when the rain comes." (On February $4^{\text {th }} 2021$ )

Teacher E said, "Almost all the students here are the local of Tumbang Rungan village. Whereas the internet access here is hard to get. Only a few areas in this village can access the internet although it is not really good. I use Telkomsel here and the signal is just EDGE. It is quite difficult to take an online class. Hence, the teachers teach from home whose location is rather to the city in order to be able to share the materials and there are some teacher who is on duty here. Thus, if the students have any questions, the can directly come to ask to the teacher. Since this area is quite far away from the city." (On February $16^{\text {th }}$ 2021)

Teacher B said, "Usually the challenge appears when it is black out. When it is black out or the rain comes, the signal is usually unstable" (On February $\left.6^{\text {th }} 2021\right)$

2. Student's learning attention

Teacher A said, "It is so different from now that they have to look for the example till they can make a video by themselves. As when asked the $9^{\text {th }}$ grade students to make a video for retelling story, they have to make it according to their language style but in English. They will be so difficult. Then, some of them do not complete that assignment." (On February $4^{\text {th }}$ 2021)

3. The instability motivation

Teacher B said, "The first time we did online learning, the students were excited. Yet, they are getting bored. I was using video in Youtube at the first time we did online learning. Evidently, it just take students' interest for 1 to 2 months. Then, they do not watch it anymore. Next, we change it into picture as a media for online learning but they sometimes open it and sometimes they do not. So that, they are getting bored. It is not because of the learning media but it is because the students' interest has been taken into another things, such as Tik Tok. So, I think it is because of their awareness. They can not handle it" (On February $6^{\text {th }}$ 2021)

Teacher E said, "The students are getting bored. I have tried to provide the the materials in various form. But I think it is because of the situation which does not support them to learn as usual. They are often late responding the process of learning. even, some of them respond a day after." (On February $\left.16^{\text {th }} 2021\right)$

Teacher C said, "Most of the students are getting bored because we have done online learning for a year. It is like they do not have ay passion and take it lightly." (On February $6^{\text {th } 2021)}$

4. Student's Financial Condition 
Teacher A said, "Some of the students do not have mobile phone and they may might come from underprivileged family. So that, they can not afford on smartphone and they are difficult to join the online learning" (On February $\left.4^{\text {th }} 2021\right)$

Teacher D said, "There are several students who do not have mobile phone. Some of them also have to alternate to use mobile phone with his younger brother/sister. So, not all students have mobile phone." (On February $11^{\text {th }}$ 2021)

Teacher E said, "We have not got any free mobile data from the government. The last accommodation was distributed last year. Then, the school also provide free mobile data for the student in the form of 200 thousand in credit. However, there are no accommodation any more these days. The students just buy themselves. Therefore, if some students do not attend the online class, we will understand because we can not enforce someone's economic condition." (On February $16^{\text {th }}$ 2021)

\section{Student's Readiness on Digital Literacy}

Teacher C said, "The first time we did online learning was really hard. As you know that the local does not really understand about technology. They may be able to call or send message but they do not understand to operate an Email and so do not the children. It is true that they can operate a mobile phone. Yet, the first few months we have to be extra teaching them the learning application and how to use an email." (On February $6^{\text {th }} 2021$ )

Teacher E also said, "The challenge also caused by the student's understanding on technology. The children who stay here does not as capable as the children who stay in city who understand more in using mobile phone. The students here can not really use mobile phone. They just understand how to play on it and send message. So that, I have to adjust to them. I have to look for the most simple learning application." (On February $16^{\text {th }} 2021$ )

\section{Parent's Concern}

Teacher B said, "There are some students who often attend the late when I check their present in Whatssapp group. I usually check them at 7 a.m. However, some students respond it about at 9 a.m. They make reasons that they are helping their parents, going to market, or getting up late. So that, they attend the class late." (On February $6^{\text {th }} 2021$ )

Teacher A said, "We usually start the class at 7 till 10 a.m. Then, the submission is no more than at 1 p.m. Thus, the students are late not only because of the signal but also because of the schedule changes. They usually still help their parents at 7 a.m or take care of their younger brother/sister. So that, they have just attended the E-Learning at 9 or 10 a.m. Then, they will also be late in submitting the task which should be collected no more than at 1 p.m. Yet, they have just submitted the task in the afternoon." (On February $\left.4^{\text {th }} 2021\right)$

Teacher C said, "The challenge also comes from their parents. Most of the parents does not support. During pandemic, most of the parents exploit their children to work. I ever got private message from the student, "I apologize for atteding the class because my parent ask me to go to the market" or "I am sorry that I was late because I was command to take care of my younger brother". It is like a big opportunity for their parent." (On February $6^{\text {th }}$ 2021) 


\section{Designing Learning Materials}

Teacher A said, 'The educational process is just as usual. The teacher deliver according to the particular schedule. Nevertheless, before entering the class, we have more responsibility because we have to prepare the materials in a file to be able to be shared online. We are the teachers of MTS Al-Amin Banturung are supposed to make a video for being uploaded in Youtube. Hence, the student can access it whenever. Unfortunately, the video editing cannot be finished in one or two hours. Because we have to make the power point, record our voice and edit it. Then, we can upload it. Thus, we need extra time and more struggle." (On February $\left.4^{\text {th }} 2021\right)$

Teacher B said, "The challenge also comes when we create the materials. Sometimes, we also have to explain the materials learnt. Usually, it creat a video to explain the materials to the students. I also have to comprase the video size to make the student easier to access is although they do not have much mobile data and good internet access. After that, I upload it in classroom. It is little bit complicated." (On February $\left.4^{\text {th }} 2021\right)$

\section{Measuring Student's Understanding}

Teacher A said, "I think when we take online learning, all materials can be found in Google. All students can access it. Then, they can get better score. Nevertheless, their understanding to the lesson is deficient. For the students who understand, they will look for more explanation in Google and read in social media. They should be better if they do that. So that, we do not really know whether the students get a good score because of their understanding or they are just cheating." (On February $4^{\text {th }} 2021$ )

Teacher D said, "Of course, because some students seldom join the online class or even they have attended the online class often but we do not really know whether the student understand or not. When we did offline learning we are a bit difficult to make sure whether the students understand. Moreover, during online learning we can not see the students directly. Indeed, need longer time to get the student's response just to make sure their understanding." (On February $11^{\text {th }}$ 2021)

Based on the interview and questionnaire result about the challenges of secondary school English teachers in remote areas toward online teaching, the researcher found that the challenges of English did not only come from the teachers but also the students and their environment. Yet, most challenge came from the student's condition and environment which did not support the online learning process.

\section{The Solution to Overcome The Challenges of Secondary School English Teachers}

The challenges appearing during online teaching could not be left by the teacher because it could cause the education system become worse more and more. The fact that the English teacher in remote areas had their own unexpeted challenges. They also did something to overcome the challenges they faced during online learning.

Teacher A said, "I usually give them more time to collect the task. As you know that the submission time is no more than 1 p.m. However, they can collect it in the afternoon or evening. I also motivate them for not being bored and remind them about their responsibility for doing the task. (On February $4^{\text {th }} 2021$ ) 
Teacher B said, "We have to be more creative, change the learning application or platform and the learning media. If I use classroom, I will be more relax. I can create an explanation video based on the materials. Then, I put the question on the video. So that, if they are curious about the question, they have to watch the video." (On February $\left.6^{\text {th }} 2021\right)$

Teacher C said, "First, for the students who does not have mobile phone, we lend them laptop form the teacher. They also can collect the task a week after the task uploaded. I also get them into a group for 2 people. So that, they can study and discuss the lesson together to be interactive. We also teach them how to operate the application used for online learning " (On February $6^{\text {th }}$ 2021)

Teacher D said, "We usually contact them personally to ask them come to school to ask for their reason why they do not attend the class as the schedule arranged and those who have not understood the lesson given during online class." (On February $\left.11^{\text {th }} 2021\right)$

Teacher E said, "I ask them to come to school and re-explain the materials which they have not understood. Also for those which does not have mobile data to access the online learning application, they can come to school too. That is why we have daily schedule for the teacher." (On February $16^{\text {th }}$ 2021)

Based on the interview result above, the researcher found that to decrease the teacher challenges in remote areas toward online teaching caused by the inadequate infrastructure such as internet access, student condition and unpredictable activities during online learning, the teacher gave their students extra time to do the task given about 2 or three hours or even a week.

\section{Discussion}

\section{The Challenges of Secondary School English Teachers}

In collecting the data, the researcher found that every English teacher experience a different challenges as the challenges not only came from the teacher but also the students and their environment as stated by Khalid (2017) that the challenges of English teacher did not only come from the internal but also external factor the researcher found that there were challenges faced by the English teacher in remote areas in Palangka Raya are more complex, as follows:

(1) lack of infrastructure, the infrastructure needed for online learning is tower. Bad internet access has already been a problem in the country especially in remote areas since the Covid-19 hit (Cuaton, 2020). It is needed to support the internet access in all areas. However, it is sometimes not spreaded equally in remote areas. Consequently, online learning can not run really well in remote areas.

(2) student's learning attention, in line with Dhawan (2020) that personal learning attention is also a huge issue facing online learning. Student's learning attention becomes the English teacher's challenge toward online learning. During online learning, the student's attention on learning is knocking down more and more since they can not directly interact to the teacher.

(3) student's financial condition, to conduct online learning, both the teacher and the student need to have learning tools, such as laptop or mobile phone and mobile data. However, not all families can afford on it because of their financial condition. The researcher also found that some of the teachers lend their students laptop for joining online learning and some students also have to use mobile phone alternately with their siblings.

(4) student's readiness; According to Guglielmino (2003) as cited in Cigdem \& Ozturk (2016, p. 99) online learning readiness refers to how good the user's competency in operating digital technology. So that student's capability in operating technology during online learning is also taken into consideration. They may operate some application, such as game and social media through their smartphone. Yet, they are not familiar with the learning application used. As a result, the English teacher in remote areas practiced them in the first month of doing online learning because of Covid-19 pandemic. 
(5) parent's concern; the parent's attention on their child activities is needed during online learning because the teacher can not keep their eye on the student as the offline learning conducted at school. Some parents may monitor their child during online learning, but they do not make sure whether their child join the online learning or not

(6) designing learning materials; designing learning materials includes to the pre-teaching activities. In order to properly designed and implemented, online learning requires greater investment that face-toface class (Green, 2016). The teacher prepare the subject materials for being explained before the class begin. They may prepare the book, power point and additional media for class. Nevertheless, online learning does let the teacher do as usual. They need double effort to design their learning materials which need extra time too before the class. The teacher needs to work over the learning materials to be able to be shared through the learning application.

(7) measuring student's understanding on subject, measuring student's understanding on subject also becomes a challenge for the teacher because they can not monitor their students during online class. It makes them difficult to measure student's understanding whether their student's really read the explanation uploaded on learning application and understand it or they just answer the task by cheating their friends. It also happens during online examination, the teacher can not directly monitor their students during examination. So that, It can be analyzed that there are some similarities to the previous study which was taken from the teacher in Indonesia while this study is taken from the English teacher in remote areas of Palangka Raya. (8) the instability of sudent's motivation, since Covid-19 pandemic was confirmed as a natural disasters by the Indonesian government issued Presidential Decree of the Repuclic Indonesia number 12 of 2020 on April 2020. The educational process was all brought into online learning. It can be seen that the students have been learning online for almost a year. Most of the teachers experience the student's response on online learning are significantly decreasing day by day. The instability of student's motivation becomes a great challenge for the teacher to re-increase the student's motivation on online learning. Yet, it is quite difficult for them to motivate the student's without having interaction directly. As the result of the interview that some teachers have done many things, such as creating an interactive media for online learning in order to take the student's interest more. However, it does not give a great impact to the student's since the environment of studying is different from school.

Based on the interview, the researcher found four main factors as the reason why the challenge could occur toward online teaching (1) The lack of student's effort, mostly it happened because of the student's laziness and interest toward online learning the fact that student had been feeling isolated for more than a year they had taken into online learning without any interaction with their friend and feel so bored. (2) Economy, during Covid-19 pandemic, almost all people experienced unstable economy. Many companies fired their employees to minimize their loss. A few of them also went bankrupt. Indeed, the economic condition of some families was not good enough also the reason of why some students could not afford on something to fulfill their needs for online learning. (3) The role of parent, during online learning some parents might keep their eye on their child activities during online learning schedule to make sure whether their child really did the online class or not. However, some parents who did not monitor their children will cause some problems occur such as, the student do not do the task and never take into online class. (4) Facilities, facilities which are needed for online learning are mobile phone or laptop, mobile data and internet access. What if one of the facilities is not available for the student or teacher? Sure, the online learning activities will not run well or being delayed. As long as the online learning done in every school without exception in remote areas, internet access is the most influential facility. Some remote areas even could not access the learning application whenever the student want because the unstable connection. Those main factors had 
to be taken into deep consideration for the continuity of online learning during Covid-19 Pandemic. If it was not handled soon, the process of online learning will not step forward and the teacher will always face the same problem as before.

All in all, in addition to the lack of facilities in remote areas, it could be identified that the students' learning preference was a key concern to stimulate the students to reach a better understanding during learning since almost all the challenges of English teacher came from the student's condition and environment, such as the economy, student's effort and their environment which support the online learning process.

\section{Overcoming The Challenges of English Teachers}

Although all possible distructions during online teaching had been handled as fast as possible. In fact, the challenges of English teachers in remote areas were still unavoidable. Based on the interview with the English teachers, to evercome those challenges, the English teacher used to give the students additional time to do their task because of the inadequate facilities in remote areas. In fact the student also had another activities to do at home and their environment did not really support them to do the task in the same time. So that, the teacher decided to give extra time for the students. Teacher's creativity was also mentioned as one of solutions to take student's interest. Their creativity in choosing the best application, arranging quiz, task, managing class and adaptive to dynamic changes were also needed (Atmojo \& Nugroho, 2020). It could make the teacher got the student's learning interest. as Miss SF said during interview that the reason why she changed the learning application was because it could make her more relax. She could also put an attractive learning media and put tasks there to increase student's motivation and curiosity. The teacher also provided some facilities for the students who did not have mobile phone or laptop to join the online class and practice the students how to operate the learning application they used during online learning. It is aimed to help the students who has low economy condition and train their students to get used to on operating the technology since the students in remote areas are lack of digital literacy.

\section{CONCLUSION}

In this study, the researcher has conducted research on The Challenges of English Teachers in Remote Areas toward Online Teaching during Covid-19 Pandemic. Based on the result of questionnaire and interview, various challenges was found during research that each English teacher experiences different challenges according to both teacher's and student's condition and situation. The challenges of the English teachers in remote areas were as follows: (1) lack of infrastructure; (2) student's learning attention; (3) student's financial condition; (4) student's readiness on digital literacy; (5) parent's concern; (6) designing learning materials; (7) measuring student's understanding; and (8) the instability of student's motivation. To overcome the challenges faced by the English teachers were by creating an attractive media for online learning, by deciding a suitable learning application or platform, by giving additional time for the students to accomplish their assignment and providing facilities for both the students and the teacher, such as mobile data.

\section{ACKNOWLEDGMENTS}

The researcher would like to her sincere gratitude to Allah SWT., for the blessing bestowed in her whole life. To all the leacturers and English teachers who have taken part in this study and who have generously shared their time, experience, and research material, I wish to express my appreciation and thank you. 


\section{REFERENCES}

Archaya, B. (2010). Questionaire Design. Training -Cum- Workshop in Research Methodology. Organised by Centre for Post-graduate Studies Nepal Engineering Collage.

Ary, D., Jacobs, L. C., \& Sorensen, C. (2010). Introduction to Research in Education (8th ed.). New York: Thomson Learning.

Atmojo, A. E. P., \& Nugroho, A. (2020). EFL classes must go online! Teaching activities and challenges during COVID-19 pandemic in Indonesia. Register Journal, 13(1), 49-76.

Cigdem, H., \& Ozturk, M. (2016). Critical components of online learning readiness and their relationships with learner achievement. Turkish Online Journal of Distance Education, 17(2).

Cuaton, G. P. (2020). Philippines higher education institutions in the time of COVID-19 pandemic. Revista Romaneasca Pentru Educatie Multidimensionala, 12(1 Sup2), 61-70.

Dhawan, S. (2020). Online learning: A panacea in the time of COVID-19 crisis. Journal of Educational Technology Systems, 49(1), 5-22.

Green, P. (2016). How to succeed with online learning. The Wiley Handbook of Learning Technology. 1st Ed, 261-286.

Kementerian Pendidikan dan Kebudayaan Indonesia. (2020). Surat Edaran Kemendikbud No. 4 Tahun 2020 Pelaksanaan Kebijakan Pendidikan dalam Masa Darurat Penyebaran Corona Viru Disease Covid 19. Jakarta, Indonesia: Kementerian Pendidikan dan Kebudayaan Indonesia. Retrieved from https://www.kemdikbud.go.id/main/blog/2020/03/se-mendikbud-pelaksanaan-kebijakanpendidikan-dalam-masa-darurat-penyebaran-covid19

Khalid, F. S. (2017). Exploring English language teachers' challenges and coping strategies in teaching slow learners in inclusive education programmes. IIUM Journal of Educational Studies, 5(2), 39-53.

Lauder, A. (2008). The Status and Function of English in Indonesia: A Review of Key Factors. Makara Human Behavior Studies in Asia, 12(1), 9-20.

Sugiyono. (2015). Metode Penelitian Kuantitatif, Kualitatif, dan Kombinasi (Mixed Methods). Bandung: Alfabeta.

World Health Organization. (2020). Coronavirus disease (COVID-19) Pandemic. United States: World Health Organization. 